\title{
The relationship between humidity, light and the activity pattern of a velvet worm, Epiperipatus sp. (Onychophora: Peripatidae), from Bahía Drake, South Pacific of Costa Rica
}

\author{
J. P. Barquero-González ${ }^{a}$, B. Morera-Brenes ${ }^{a}$ and J. Monge-Nájera ${ }^{b}$ \\ ${ }^{a}$ Laboratorio de Sistemática, Genética y Evolución - LabSGE, Escuela de Ciencias Biológicas, \\ Universidad Nacional, Heredia, Costa Rica \\ ${ }^{b}$ Laboratorio de Ecología Urbana, Universidad Estatal a Distancia - UNED, 2050 San José, Costa Rica \\ *e-mail: jopbgon@gmail.com
}

Received: July 11, 2016 - Accepted: January 11, 2017 - Distributed: October 31, 2018

(With 5 figures)

\begin{abstract}
Even though the Onychophora represent a whole phylum, observations of their activity pattern in nature are almost non-existent. Here we report on the relationship between humidity and light and activity pattern of a new species of velvet worm, genus Epiperipatus, from four years of field observations in the South Pacific of Costa Rica. We found that most activity occurs during the driest and darkest nights of the year, in contrast with theoretical predictions.
\end{abstract}

Keywords: Onychophora, activity pattern, ecology, behavior.

\section{A relação entre a humidade, luz e o padrão de atividade de um peripato, Epiperipatus sp. (Onychophora: Peripatidae), de Bahia Drake, Pacífico Sul da Costa Rica}

\begin{abstract}
Resumo
Onychophora constituem um filo de animais. Não obstante, as observações do comportamento sazonal das espécies de "peripatos" na natureza são praticamente inexistentes. Com base em quatro anos de observações em campo, nós demostramos a relação entre umidade e luz, e padrão de atividade diária de uma nova espécie no gênero Epiperipatus, do Pacífico Sul da Costa Rica. Descobrimos que a maioria das atividades ocorre durante as noites mais secas e mais escuras do ano, em total contraste com as previsões teóricas.
\end{abstract}

Palavras-chave: Onychophora, Peripatus, ecologia, comportamento.

\section{Introduction}

Onychophorans, or velvet worms, are organisms with an extraordinary biology that remain poorly understood because of their cryptic lifestyle and rarity in the most ecosystems, particularly in the tropics (Podsiadlowski et al., 2008; Sampaio-Costa et al., 2009; Brito et al., 2010; Rota-Stabelli et al., 2010; Lacorte et al., 2011; Morera-Brenes, 2012; Chagas-Júnior and Sampaio-Costa, 2014). In fact, most biologists never see them alive. The phylum Onychophora has approximately 200 known species, but there are almost no observations about their foraging behavior under natural conditions. Consequently, any data on hitherto unknown aspects of their behavior and life history are urgently needed.

Onychophorans usually inhabit dark and moist microhabitats, chiefly in forest litter, stones, moss, rotten logs, soil crevices, ant or termite tunnels, and less frequently, bromeliads (Picado, 1911; Carvalho, 1941; Monge-Nájera, 1995; Grimaldi and Engel, 2005).

Out of hundreds of species, the foraging behavior is known only for Macroperipatus torquatus (Kennel, 1885). This predator occupies the third trophic level in the forest ecosystem and usually begins hunting just after dusk, returning to its hiding place before sunrise (Read and Hughes, 1987; Read, 1988). To forage, it sweeps its head from side to side in slow steady movements, and potential prey are inspected by gentle application of the antennae (Ghiselin, 1985; Read and Hughes, 1987). In general, Onychophorans feed on small invertebrates captured with a proteinaceous adhesive net; the net is self-assembled in a fraction of a second and is also expelled as a defense (Bouvier, 1905; Concha et al., 2015). The animal then injects digestive fluids into the prey (Read and Hughes, 1987; Morera-Brenes and Monge-Nájera, 2010). There is 
no information about the influence of climatic seasonality on individual activities of any onychophoran species, a knowledge that is not only needed to understand their ecology and evolution, but also for their conservation (Vasconcellos et al., 2006).

Recently, Barquero-Gonzalez et al. (2016) examined a series of records of unknown Costa Rican onychophoran species photographed while foraging, but no additional information about their activity patterns was available. Here we analyze some ecological parameters about the activity pattern of one of those undescribed species, Epiperipatus sp. (Peripatidae) from Bahía Drake, South Pacific of Costa Rica, and associate behavior with ecological conditions based on four years of field data.

\section{Material and Methods}

Data were collected from 2012 through 2015 by the staff of The Night Tour with Tracie Stice, "The Bug Lady", a field tour in Bahía Drake, South Pacific of Costa Rica (N 08.69420-08.69490; W 083.67421-W 083.67495) (Figures 1 and 2). Counts were done mostly from $7: 30$ to $10 \mathrm{PM}$ with head flashlights (a few started at 5:30 and ended at 10:45 PM). Most observations were made near the Agujas River, 12 to $38 \mathrm{~m}$ above sea level. Climatic data were kindly provided by the tour company. A multiple regression indicated that moonlight and rain were correlated but failed to find a significant predictor, so we decided to apply individual non-parametric tests instead (tests are detailed in figure captions for clarity). Detailed statistical analyses and original raw data appear complete in Appendix 1.

\section{Results}

On the average, about 20 counting trips were made every month and, also on average, one onychophoran was seen for every three nights of field work. The number of observations peaked in the "dry season" (December-April) and was lowest in the rainy days of June through September (Figure 3). Note that, considering the high rainfall levels in the Costa Rican Southern Pacific, the "dry season" can be better described as "less rainy season".

When the specific humidity at the site was analyzed, it was clear that most sightings were made on dry nights, with extremely few observations when it was raining at the time of the tour (Figure 4).

Few individuals were seen active in the field when moonlight produced bright or semi-bright night conditions. Most sightings were made on dark nights (Figure 5).

\section{Discussion}

Tasmanipatus barretti and T. anophthalmus (Ruthberg et al., 1991) [Peripatopsidae] from Tasmania have not been reported to forage at night (Mesibov and Ruthberg, 1991), but M. torquatus, from Trinidad in the Caribbean sea, forages every few weeks, or weekly in the case of

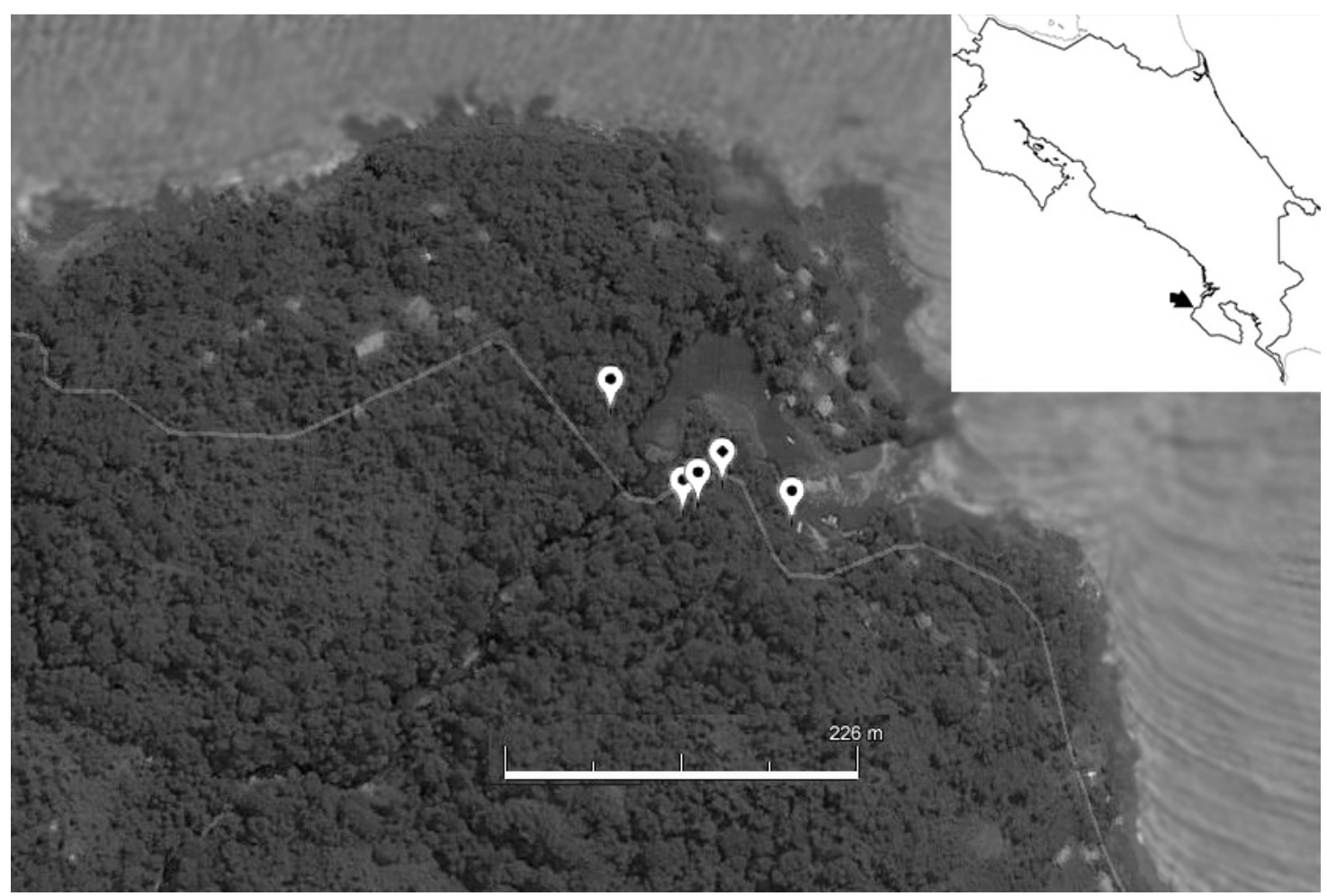

Figure 1. Sites of the field observations of Epiperipatus sp. foraging at night, Bahía Drake, South Pacific of Costa Rica (based on Google Earth). 




Figure 2. Adult and offspring of Epiperipatus sp. in their habitat, from Bahía Drake, South Pacific of Costa Rica. Photograph by Gianfranco Gómez and Tracie Stice.

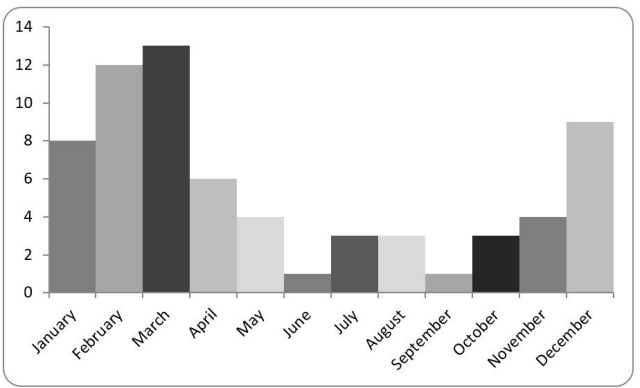

Figure 3. Monthly number of Onychophoran individuals foraging at night during four years (2012-2015), at the South Pacific of Costa Rica. Chi-Squared $23.45 \mathrm{p}<0.0001$.

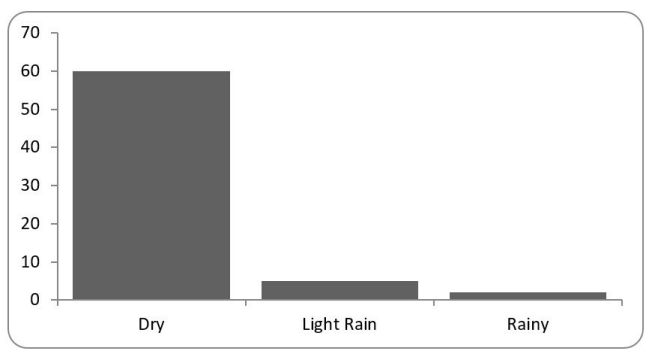

Figure 4. Number of Onychophoran individuals seen according to rain conditions, during four years (2012-2015), at the South Pacific of Costa Rica. Chi-Squared $96.46 \mathrm{p}<0.0001$.

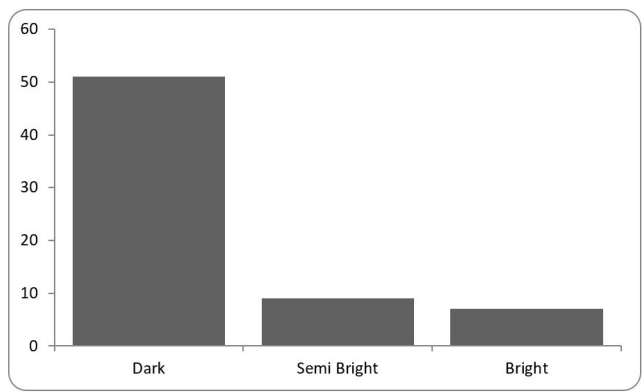

Figure 5. Number of Onychophoran individuals seen according to light conditions in the forest undergrowth, during four years (2012-2015), at the South Pacific of Costa Rica. Chi-Squared $55.29 \mathrm{p}<0.0001$. smaller individuals, which may be unable to capture larger prey and thus must feed more often. The behavior of this Costa Rican Epiperipatus sp., which patrols its home range at night in search of food, is thus closer to the behavior of M. torquatus (Read, 1985; Read and Hughes 1987).

Given the vulnerability to desiccation that is characteristic of these worms (Hardie, 1975; Tait et al., 1990), we expected a preference for more humid environments and nights. This is the case of another Peripatidae, Epiperipatus acacioi from Brazil, which remains underground when temperatures are low or the soil is relatively dry, but disperse on the surface when conditions improve (Lavallard et al., 1975). M. torquatus shows the same behavior: it is not seen foraging on the surface until the start of the rainy season (Read, 1985). In any case, the animals observed for this study show the opposite pattern: they seem to avoid foraging on the rainy season, and a possible reason is explained below.

Monge-Nájera's (1995) idea, i.e. that increased moisture will increase onychophoran activity during rainy periods, fit previous observations (Lavallard et al., 1975; Read, 1985). Why is Epiperipatus sp. different? The animals observed for this study were found near a Costa Rican Southern Pacific river bed, where humidity is high year round. Some small tropical invertebrates reduce their activity on very rainy periods, apparently to avoid the negative effects of being hit by the cold raindrops, which to them are relatively large (Barrientos, 2016), and this might apply to Epiperipatus sp. (Zaidett Barrientos, 2016, pers. comm.). A second possibility is that velvet worms vacate the surface on periods of heavy rain to avoid being washed away from their territories into new and possibly unsuitable habitats (see Morrison, 1946). We recommend experiments on these hypotheses as an interesting option for future research.

The animals seem to be less active on the surface in nights with higher light levels, perhaps to avoid visually guided predators (see Barclay et al., 2000). Most foraging activity by $M$. torquatus occurred between 19:30 h and 21:30 h (Read and Hughes, 1987), the same range of our observations with Epiperipatus sp. A possible explanation of why onychophorans only forage until midnight is that if they capture prey, they still need several hours to externally digest and later consume it. If they hunted after midnight, they would still be on the surface when the sun rises, becoming exposed to desiccation and daytime predators (see Read and Hughes, 1987; Monge-Nájera et al., 1993).

A few populations of velvet worms in Oceania may be relatively abundant, but in the rest of the World most species are extremely rare (a review of densities appears in Monge-Nájera, 1995). Their rarity and secretiveness makes any information especially valuable for conservation efforts. We hope this article will inspire others to collect similar data and add to our knowledge of this extraordinary group of invertebrates. 


\section{Acknowledgements}

We greatly appreciate Gianfranco Gómez and Tracie Stice for graciously sharing their database and other information with us, and one anonymous reviewer for suggestions to improve the article.

\section{References}

BARCLAY, S., ASH, J.E. and ROWELL, D.M., 2000. Environmental factors influencing the presence and abundance of a log-dwelling invertebrate, Euperipatoides rowelli (Onychophora: Peripatopsidae). Journal of Zoology, vol. 250, no. 4, pp. 425-436. http://dx.doi.org/10.1111/j.1469-7998.2000.tb00786.x.

BARQUERO-GONZALEZ, J.P., ACOSTA-CHAVES, V.J., SOTELA-BLANCO, L., VILLALOBOS BRENES, F. and MORERA-BRENES, B., 2016. Evidencia fotográfica de especies desconocidas de onicóforos (Onychophora: Peripatidae) de Costa Rica. Cuadernos de Investigación UNED, vol. 8, no. 2, pp. 139-147.

BARRIENTOS, Z., 2016. Reproductive system, mating behavior and basic ecology of an extremely rare tropical snail: Drymaeus tripictus (Stylommatophora: Bulimulidae). Revista de Biología Tropical, vol. 64, no. 1, pp. 55-68.

BOUVIER, E. L., 1905. Monographie des Onychophores I. Annales des Sciences Naturelles, vol. 2, no. 9, pp. 1-384.

BRITO, S.V., PEREIRA, J.C., FERREIRA, F.S., VASCONCELLOS, A. and ALMEIDA, W.O., 2010. Epiperipatus cratensis sp. nov. (Onychophora: Peripatidae) from northeastern Brazil. Neotropical Biology and Conservation, vol. 5, no. 1, pp. 47-52. http://dx.doi. org/10.4013/nbc.2010.51.07.

CARVALHO, A.L., 1941. Nota prévia sôbre uma nova espécie de "Peripatus" do Brasil Central. Brazilian Journal of Biology $=$ Revista Brasileira de Biologia, vol. 1, no. 4, pp. 447-448.

CHAGAS-JÚNIOR, A. and SAMPAIO-COSTA, C.S., 2014. Macroperipatus ohausi: redescription and taxonomic notes on its status (Onychophora: Peripatidae). Revista de Biología Tropical, vol. 62, no. 3, pp. 977-985. PMid:25412530. http:// dx.doi.org/10.15517/rbt.v62i3.11643.

CONCHA, A., MELLADO, P., MORERA-BRENES, B., SAMPAIO COSTA, C., MAHADEVAN, L. and MONGENAJERA, J., 2015. Oscillation of the velvet worm slime jet by passive hydrodynamic instability. Nature Communications, vol. 6, no. 6292. PMid:25780995.

GHISELIN, M.T., 1985. A movable feaster. Natural History, vol. 94 , no. 9 , pp. 54-54.

GRIMALDI, D. and ENGEL, M.S., 2005. Evolution of the insects. Cambridge: Cambridge University Press. 755 p.

HARDIE, R., 1975. The riddle of peripatus. Australian Natural History, vol. 18, pp. 180-185.

KENNEL, J.V., 1885. Entwicklungsgeschichte von Peripatus edwardsii Blanch. und Peripatus torquatus $n$. sp. Arbeiten aus dem Zoologischen Institut, vol. 7, pp. 95-229.

LACORTE, G.A., OLIVEIRA, I.S. and FONSECA, C.G., 2011. Population structure and demographic inferences of the endangered onychophoran species Epiperipatus acacioi (Onychophora: Peripatidae). Genetics and Molecular Research, vol. 10, no. 4, pp. 2775-2785. PMid:22095603. http://dx.doi.org/10.4238/2011. November.9.1.
LAVALLARD, R., CAMPIGLIA, S., PARISIALVAREZ, L. and VALLE, C.M.C., 1975. Contribution a la biologie de Peripatus acacioi Marcus et Marcus (Onychophore). III. Etude descriptive de l'habitat. Vie et Milieu, vol. 25, pp. 87-118.

MESIBOV, R. and RUTHBERG, H., 1991. Ecology and conservation of Tasmanipatus barretti and T. anophthalmus, parapatric onychophorans (Onychophora: Peripatopsidae) from northeastern Tasmania. Papers and Proceedings of the Royal Society of Tasmania, vol. 125, pp. 11-16.

MONGE-NÁJERA, J., 1995. Phylogeny, biogeography and reproductive trends in the Onychophora. Zoological Journal of the Linnean Society, vol. 114, no. 1, pp. 21-60. http://dx.doi. org/10.1111/j.1096-3642.1995.tb00111.x.

MONGE-NÁJERA, J., BARRIENTOS, Z. and AGUILAR, F., 1993. Behavior of Epiperipatus biolleyi (Onychophora: Peripatidae) under laboratory conditions. Revista de Biología Tropical, vol. 41, no. 3A, pp. 689-696.

MORERA-BRENES, B. and MONGE-NÁJERA, J., 2010. A new giant species of placented worm and the mechanism by which onychophorans weave their nets (Onychophora: Peripatidae). Revista de Biología Tropical, vol. 58, no. 4, pp. 1127-1142. PMid:21246983. http://dx.doi.org/10.15517/rbt.v58i4.5398.

MORERA-BRENES, B., 2012. Los onicóforos, fósiles caminantes. El Salvador Ciencia and Tecnología, vol. 17, no. 23, pp. 8-13.

MORRISON, P.R., 1946. Physiological observations on water loss and oxygen consumption in Peripatus. The Biological Bulletin, vol. 91, no. 2, pp. 181-188. PMid:20275342. http:// dx.doi.org/10.2307/1538259.

PICADO, C., 1911. Sur un habitat nouveau des Peripatus. Bulletin du Musée National d'Histoire Naturelle, vol. 17, pp. 415-416.

PODSIADLOWSKI, L., BRABAND, A. and MAYER, G., 2008. The complete mitochondrial genome of the onychophoran Epiperipatus biolleyi reveals a unique transfer RNA set and provides further support for the Ecdysozoa hypothesis. Molecular Biology and Evolution, vol. 25, no. 1, pp. 42-51. PMid:17934206. http:// dx.doi.org/10.1093/molbev/msm223.

READ, V.S.J. and HUGHES, R.N., 1987. Feeding behaviour and prey choice in Macroperipatus torquatus (Onychophora). Proceedings of the Royal Society of London. Series B, Biological Sciences, vol. 230, no. 1261, pp. 483-506. http://dx.doi.org/10.1098/ rspb.1987.0030.

READ, V.S.J., 1985. The ecology of Macroperipatus torquatus (Kennel), with special reference to feeding and a taxonomic review. Bangor, Wales, United Kingdom: University of Wales. Ph.D. Thesis.

READ, V.S.J., 1988. The Onychophora of Trinidad, Tobago and the Lesser Antilles. Zoological Journal of the Linnean Society, vol. 93, no. 3, pp. 225-257. http://dx.doi.org/10.1111/j.1096-3642.1988. tb01362.x.

ROTA-STABELLI, O., KAYAL, E., GLEESON, D., DAUB, J., BOORE, J.L., TELFORD, M.J., PISANI, D., BLAXTER, M. and LAVROV, D.V., 2010. Ecdysozoan mitogenomics: evidence for a common origin of the legged invertebrates, the Panarthropoda. Genome Biology and Evolution, vol. 2, pp. 425440. PMid:20624745. http://dx.doi.org/10.1093/gbe/evq030.

RUTHBERG, H., MESIBOV, R., BRISCOE, D.A. and TAIT, N.N., 1991. Tasmanipatus barretti gen. nov., sp. nov. and T. anophthalmus sp. nov.: two new and unusual onychophorans (Onychophora: Peripatopsidae) from northeastern Tasmania. 
Papers and Proceedings of the Royal Society of Tasmania, vol. 125, pp. 7-10.

SAMPAIO-COSTA, C., CHAGAS-JUNIOR, A. and BAPTISTA, R.L.C., 2009. Brazilian species of Onychophora with notes on their taxonomy and distribution. Zoologia, vol. 26, no. 3, pp. 553-561. http://dx.doi.org/10.1590/S1984-46702009005000004.

TAIT, N.N., STUTCHBURY, R.J. and BRISCOE, D.A., 1990.

Review of the discovery and identification of Onychophora in
Australia. Proceedings of the Linnean Society of New South Wales, vol. 112, pp. 153-171.

VASCONCELLOS, A., ALMEIDA, W.O. and SOUZA, L.A., 2006. Onychophora in humid forests of northeastern Brazil. Brazilian Journal of Biology = Revista Brasileira de Biologia, vol. 66, no. 1A, pp. 187-189. PMid:16680322. http://dx.doi. org/10.1590/S1519-69842006000100024. 
Appendix 1. Detailed statistical analysis.

Cross tabulation of correlations, all variables. Pearson Correlations. $\mathrm{N}=63$ cases.

\begin{tabular}{lcccc}
\hline & $\begin{array}{c}\text { Number of worms seen } \\
\text { per night }\end{array}$ & $\begin{array}{c}\text { Rain } \\
\text { (dry, light rain or rainy) }\end{array}$ & $\begin{array}{c}\text { Light level } \\
\text { (dark, semi-bright, bright) }\end{array}$ & Moon (phase) \\
\hline Number & 1 & -0.039 & 0.28 & -0.029 \\
Rain & -0.039 & 1 & -0.029 & 0.508 \\
Light & 0.28 & -0.029 & 1 & 0.123 \\
Moon & -0.029 & 0.508 & 0.123 & 1 \\
\hline
\end{tabular}

Multiple Regression: Correlation Matrix

\begin{tabular}{ccccc}
\hline & X1 Moonlight (\%) & X2 Rain (present/absent) & X3 Moon Phase & Y \\
\hline X1 & 1 & -0.029 & 0.508 & -0.039 \\
X2 & -0.029 & 1 & 0.123 & 0.28 \\
X3 & 0.508 & 0.123 & 1 & -0.029 \\
Y & -0.039 & 0.28 & -0.029 & 1 \\
\hline
\end{tabular}

Number of variables $=3 \mathrm{X}$ and $1 \mathrm{Y}$. Observations per variable $=63$

Regression Coefficients for number of worms seen (Y):

Multiple regression equation $Y=a+b_{1} X_{1}+b_{2} X_{2}+\cdots+b_{k} X_{k}$.

\begin{tabular}{lccc}
\hline & b & B & B $\mathbf{~ r ~}_{\mathbf{x y}}$ \\
\hline X1 Moonlight (\%) & 0.0013 & 0.0037 & -0.0001 \\
X2 Rain (present/absent) & 0.1948 & 0.2886 & 0.0809 \\
X3 Moon Phase & -0.0005 & -0.0666 & 0.0019 \\
Multiple $\mathbf{R}^{2}=0.0827$ & & & \\
Adjusted Multiple $\mathbf{R}^{2}=0.036$ & & & \\
Standard Error of Multiple Estimate & 0.2354 & & \\
\hline
\end{tabular}

ANOVA Table .

\begin{tabular}{llcccc}
\hline \multicolumn{1}{c}{ Source } & SS & df & MS & F & P \\
\hline Regression & 0.3098 & 3 & 0.1033 & 1.77 & 0.1627 \\
Residual & 3.4362 & 59 & 0.0582 & & \\
Total & 3.746 & 62 & & & \\
\hline
\end{tabular}

Codes: Light Conditions Dark 1 Semi-Bright 2 Bright 3 Weather Conditions Dry 1 Very light Rain 2 Rainy 3 Time 5:30-8:00 1 7:30-10:30 2 7:30-10:50 3 Moonrise AM 0-3:00 a.m. 1 3:00-6:00 2 6:00-9:00 a.m. 3 9:00-12 md 4 PM 12 md- 3:00 5 3:00- 6:00 6 6:00-9:00 7 9:00-12:00 8 